\title{
Perceived Ease of Use on Purchase Intention of Mobile Commerce Application
}

\author{
Dienur Muhammad Rahadian Fachrulamry ${ }^{1, *}$ Heny Hendrayati ${ }^{2}$
}

\author{
${ }^{1}$ Universitas Pendidikan Indonesia \\ ${ }^{2}$ Universitas Pendidikan Indonesia \\ *Corresponding author.Email: dienur.muhammad@student.upi.edu
}

\begin{abstract}
The use of mobile commerce applications by consumers in the process of online buying and selling activities in Indonesia is still low, which happens because of a lack of interest in using mobile commerce applications. Therefore, this study was conducted to obtain an overview of the effect of perceived ease of use simultaneously or partially on the interest in using mobile commerce in Indonesia. The method used in this study was an explanatory survey with the object of e-commerce consumer research in Indonesia with a sample size (n) of 400. The sampling technique used was the simple random sampling and the result showed that perceived ease of use had an effect on interest in the using the mobile commerce applications. The results of the study showed that Indonesian e-commerce consumers considered the importance of perceived ease of use before using mobile commerce applications because it is related to consumer behavior about how individuals wish to use a system that provides convenience.
\end{abstract}

Keywords: Behavior Intention, E-Commerce, M-Commerce, M-Commerce Application, Perceived Ease Of Use.

\section{INTRODUCTION}

Indonesia has enormous potential in the development and growth of the e-commerce industry, which until now has been strongly influenced by the advancement of internet technology and the number of smartphone users [1].

Consumer buying interest is an essential factor in the e-commerce industry because it has a big influence on consumers' tendency to do online shopping. Competitive technological developments at this time have made a large contribution in the business world [2] since consumers' high buying interest will encourage them to make purchasing decisions for a product [3]. Measuring buying interest in the e-commerce industry will provide an indication of consumer behavior to transact online [4].

In fact, consumer interest in using mobile commerce applications is not in line with the conditions existed so far. Based on the [5], consumer interest in using mobile commerce applications in Indonesia was low. Consumers did prefer to visit e-commerce websites using a PC or laptop. This was caused by a lack of experience and knowledge of consumers in making transactions via mobile commerce application. Generally, consumers only use smartphones to get product information and then they do not use it to make purchase transactions through mobile commerce applications [6, 7]. Most Indonesian consumers have not fully utilized the mobile commerce application on smartphone [8]

The impact of the low interest in using mobile commerce applications will result in low consumer purchasing decisions and the survival of the corporations [9].

Cases of low consumer interest in using mobile commerce applications had also been analyzed by researchers in several countries such as America, Saudi Arabia, Malaysia, Thailand and Indonesia [10-15]. This indicates that mobile commerce needs to be developed by increasing consumer interest in transactions. Therefore, consumers who want to choose from various alternative goods are confident of the services and attractive features available on the mobile commerce application $[7,16]$.

The lower number of mobile commerce application users than e-commerce website users is an indication that e-commerce consumers in Indonesia are not 
interested in using mobile commerce applications. The small number of mobile commerce applications users in 2018 can be seen from the percentage comparison between the numbers of consumers of e-commerce website users by $2.4 \%$. Users of mobile commerce applications in 2017 were 3,780,308 people lower than e-commerce website users of $98,033,000$ people. The data shows that generally, e-commerce startup sales transactions in Indonesia were done more often through websites or desktop and not by downloading mobile commerce applications and conducting transactions online using a smartphone [17].

One of the factors that influence interest in using mobile commerce is perceived ease of use [14]. The effect of perceived ease of use on the attitude of using mobile commerce is expected to have a positive impact because of convenience factors felt by users in carrying out transactions through mobile commerce. Hence, users are also expected to be positive to use this information technology, so that they can get many benefits while using mobile commerce [18].

Moreover, the higher the level of perceived ease of use, the higher the consumer's buying interest. When consumers feel that a product is understandable and easy to use, they tend to be interested in using the product [19].

Perceived ease of use is part of the psychological factors of consumers to determine a person's level of confidence in using a system, so that he does not require hard work in making decisions [20]. The dimensions of perceived ease of use consist of 1) a clear and understandable system, 2) effortless, and 3) an easy-touse system [21-24].

There are several models used to study consumer attitudes according to [25]. He stated that several variables are able to determine the form of attitude because there are multi attributes in it. These variables include: 1) attribute, 2) belief, 3) importance, 4) social norm, 5) attitude towards the act and object, and 6) perceived behavioral control.

Reference [26] mentioned that buying interest arises when consumers feel they have a tendency to make purchases of a brand or take actions related to purchases. It is measured by the level of possibility when consumers make a purchase. The researcher took several dimensions of interest consisting of 1) service characteristics, 2) attention, 3) interests, and 4) desires according to [27-29].

Creating perceived ease of use for e-commerce website users is an important factor for e-commerce companies to increase interest in using mobile commerce applications.

\section{METHODS}

This study aims to determine the depiction and the effect of perceived ease of use on interest in using mobile commerce applications. This study used an explanatory survey with the research object of Indonesian e-commerce consumers who previously used e-commerce websites. The sampling technique used quota sampling with a total of 400 samples. The data analysis technique was multiple linear regressions with the SPSS 22.0 for Windows program.

\section{RESULTS AND DISCUSSION}

Demographically, West Java, DKI Jakarta, and Central Java dominated the highest number of 400 samples taking. Reliability test aims to get the level of accuracy of the data collection tools. Based on the test results, it showed that an instrument was reliable enough to be used as a data collection tool because the instrument was good.

If an instrument is considered reliable, then the data generated are also accounted for. This is because the results are quite consistent, so that the instrument is reliable or dependable. Instrument reliability testing can be done with an internal consistency with a split-half technique analyzed using Spearman-Brown formula as proposed by [30] can be seen in (1).

$r_{1}=\frac{2 r_{b}}{1+r_{b}}$

Information:

$\mathrm{r}_{\mathrm{i}} \quad=$ internal reliability of all instruments

$\mathrm{r}_{\mathrm{b}} \quad=$ product moment correlation between the first and second part

The reliability test decision is determined by the following criteria:

If the internal coefficients of all items $\left(r_{i}\right)>r_{\text {table }}$ with a significance level of $5 \%$, the question items are considered reliable.

If the internal coefficients of all items $\left(r_{i}\right)<r_{\text {table }}$ with a significance level of $5 \%$, the item questions are considered unreliable.

Based on the number of questionnaires given to 30 respondents with a significance level of $5 \%$ and degrees of freedom $(\mathrm{df}) \mathrm{n}-2(30-2=28)$, the $\mathrm{r}_{\text {table }}$ produces a value of 0.361 . The results of instrument reliability testing conducted with the help of the SPSS 22.0 for Windows program indicated that all variables were reliable. This was because the value of $r_{\text {count }}$ was greater

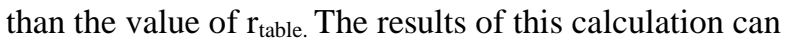
be seen in Table 1 . 
Tabel 1. Reliability testing results

\begin{tabular}{|l|l|l|l|l|}
\hline No & Variable & rcount & $\begin{array}{l}\mathbf{r} \\
\text { table }\end{array}$ & Information \\
\hline 1 & $\begin{array}{l}\text { Perceived } \\
\text { Ease of Use }\end{array}$ & 0,811 & 0,361 & Reliable \\
\hline 2 & $\begin{array}{l}\text { Interest in } \\
\text { Using }\end{array}$ & 0,772 & 0,361 & Reliable \\
\hline
\end{tabular}

Since the study analyzed more than two variables, the multiple linear regression analysis techniques were used. Reference [30] suggested that Multiple Linear regression analysis is used if the researcher intends to predict the condition (rise and fall) of the dependent variable; if there are two or more independent variables in the study as predictive factors manipulated. The formula of multiple linear regressions can be seen in (2).

$\mathrm{Y}=\mathrm{a}+\mathrm{b}_{1} \mathrm{X}_{1}+\mathrm{b}_{2} \mathrm{X}_{2}+\ldots+\mathrm{bnX}$

Information:

Y

: dependent variable (interest in using)

a

: constants

b1,b2

: regression coefficient

$\mathrm{X} 1, \mathrm{X} 2 \quad$ : independent variables (social work environment and quality of work life)

To solve this equation, the (3), (4), (5) formulas are needed:

$\mathrm{a}=\overline{\mathrm{Y}}-\mathrm{b}_{1} \mathrm{X}_{1}-\mathrm{b}_{2} \mathrm{X}_{2}$

$\mathrm{b}_{1}=\frac{\left(\Sigma x_{2}^{2}\right)\left(\sum x_{1} y\right)-\left(\sum x_{1} x_{2}\right)\left(\sum x_{2} y\right)}{\left(\Sigma x^{2}\right)\left(\Sigma x^{2}\right)-\left(\sum x_{1} x_{2}\right) x^{2}}$

$\mathrm{b}_{2}=\frac{\left(\Sigma x_{1}^{2}\right)\left(\sum x_{2} y\right)-\left(\sum x_{1} x_{2}\right)\left(\sum x_{1} y_{1}\right)}{\left(\Sigma x_{1}^{2}\right)\left(\Sigma x_{2}^{2}\right)-\left(\sum x_{1} x_{2}\right)^{2}}$

The formulas needed to calculate $\mathrm{a}, \mathrm{b} 1$ and $\mathrm{b} 2 \mathrm{can}$ be seen in (6), (7), (8), (9), (10) and (11).

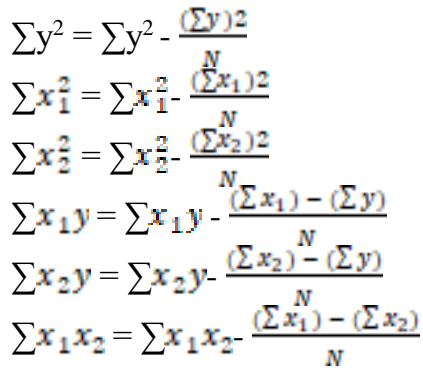

Perceived ease of use is considered to affect interest in using if the value of perceived ease of use changes causing a change in the value of interest using; rising and falling of perceived ease of use will make the interest using value also go up and down. Therefore, the value of interest using will vary, but the variable interest using value is not solely caused by perceived ease of use because there are still other factors influence it.

Based on the results of descriptive data analysis techniques, it was obtained a depiction that perceived ease of use was in a high category. It could be seen from the highest dimensions, namely the system was clear and easy to understand, did not require much effort, and easy to use.

Mobile commerce applications have a clear and easy-to-understand system for users to search for information. It also has simple features, and customers are guaranteed safety while using the application [32]. The description of how much interest in using the application could be seen from the highest dimensions consisting of the characteristics of service, attention, interest, and desire. A person can easily choose and leave a service if they feel uncomfortable when using a system [17].

T-Test was applied to determine the significant effect between independent variables and the dependent variable. $\mathrm{T}_{\text {count }}$ based on perceived ease of use was 7,304 , while $t_{\text {table }}$ was 1,649 . Because the value of $t_{\text {count }}>$ $\mathrm{t}$ table; perceived ease of use $=7.304>1,649$, it was concluded that Ho was rejected and Ha was accepted. The formulation of the accepted hypothesis was there was a positive effect of perceived ease of use on interest in using mobile commerce applications.

The test results were in line with the results of an empirical research study, which stated that there was a significant influence between perceived ease of use and interest in using applications because the higher perceived ease of use the higher the interest in using application [32]. When consumers feel that a product is easy to understood and useful, they tend to be interested in using the product $[19,33]$.

Perceived ease of use that successfully influences users will increase interest in using mobile commerce applications. Therefore, e-commerce companies need to understand and improve the perceived ease of use from the factors that influence it. This is consistent with a research conducted by [15], which revealed that perceived ease of use had a direct and positive influence on attitudes and towards the use of mobile commerce. The attitude in using mobile commerce had a significant impact on the interest of using mobile commerce.

Theoretically, perceived ease of use had a positive relationship with the interest in using the application. Based on empirical research, it can be concluded that perceived ease of use had an influence on interest in using the application with the percentage of $33.8 \%$.

\section{CONCLUSIONS}

Based on the results of this research, perceived ease of use had a positive and significant effect on interest in using the application. The dimension of easy-tounderstand system had the highest score, which proved that the mobile commerce system had received appreciation or positive response from the users. 


\section{ACKNOWLEDGMENTS}

The researcher expressed gratitude to the Postgraduate School of UPI Bandung, especially the Advisor of Program Study of Management. Furthermore, the research respondents who have contributed to the success of this research. This research will not be possible without the support of various parties.

\section{REFERENCES}

[1] Menkominfo, "Data Statistik Indonesia," Kementrian Komunikasi dan Informatika Republik Indonesia, 2018. [Online]. Available: https://kominfo.go.id/.

[2] Y. Yuliana and E. Tarmedi, "Pengaruh perbedaan individu terhadap keputusan menggunakan sistem operasi linux,” J. Bus. Manag. Educ., 2016.

[3] E. Dwityanti, “Analisis faktor-faktor yang mempengaruhi minat beli konsumen terhadap layanan internet banking mandiri studi kasus pada karyawan Departemen Pekerjaan Umum Jakarta," J. Adm. Bisnis, 2008.

[4] A. Gurung, "Empirical investigation of the relationship of privacy, security and trust with behavioral intention to transact in e-commerce," no. May, 2006.

[5] Ericsson Consumer Lab, "Eurupe Ericsson Mobility Report Appendix,” Ericsson Mobil. Rep., 2015.

[6] C. B. Liat and Y. Shi Wuan, "(For methodology)Factors influencing consumers' online purchase intention: A study among university students in Malaysia," Int. J. Lib. Arts Soc. Sci., 2014.

[7] W. M. Lim and D. H. Ting, "E-shopping: An analysis of the technology acceptance model," Mod. Appl. Sci., 2012.

[8] Marketing.co.id, "Mobile Commerce Application Indonesian Users." [Online]. Available: www.marketing.co.id. [Accessed: 25-May-2019].

[9] F. Putri, S. Kumadji, and S. Sunarti, "Pengaruh word of mouth terhadap minat beli dan dampaknya pada keputusan pembelian (Survei pada konsumen Legipait Coffeeshop Malang)," J. Adm. Bisnis S1 Univ. Brawijaya, 2016.

[10] L. Gitau and D. Nzuki, "Analysis of determinants of m-commerce adoption by online consumers," Int. J. Business, Humanit. Technol., 2014.
[11]H. Zarrad and M. Debabi, "Online purchasing intention: Factors and effects," Int. Bus. Manag., 2012.

[12] T. Ramayah and J. Ignatius, "Impact of perceived usefulness, perceived ease of use and perceived enjoyment on intention to shop online," ICFAI J. Syst. Manag., 2005.

[13]P. A. Pavlou, "An integrative model of mobile commerce adoption,” Purchasing, 2007.

[14] T. T. Wei, G. Marthandan, A. Y. L. Chong, K. B. Ooi, and S. Arumugam, "What drives Malaysian m-commerce adoption? An empirical analysis,' Ind. Manag. Data Syst., 2009.

[15] J. Trivedi and D. Kumar, "Determinants of mobile commerce acceptance amongst Gen Y," 2014.

[16]K. Prakash and Balachandra, "Security issues and challenges in mobile computing and $\mathrm{m}$ commerce,” Int. J. Comput. Sci. Eng. Surv., 2015.

[17] Dailysocial, "E-commerce startup sales transactions in Indonesia," Dailysocial.net, 2019. [Online]. Available: www.dailysocial.net [Accessed: 17-May-2019].

[18]Z. Baridwan and M. W. Sari, "Sikap penggunaan mobile commerce: modifikasi teori Technology Acceptance Model,” J. Ilm. Mhs. Feb, 2013.

[19]Y. H. Wibisono, "Faktor-faktor yang mempengaruhi perilaku pembelian dengan perilaku niat sebagai variabel intervening pada situs kaskus.Surabaya: Universitas Katolik Widya Mandala.," Kaji. Ilm. Mhs. Manaj., 2012.

[20]N. Arthana, W. Yudhi, Rukhviyanti, "Pengaruh minat individu terhadap penggunaan Mobile Banking (M-Banking): Model kombinasi Technology Acceptance Model (TAM) dan Theory of Planned Behavior (TPB),” J. Inf., 2015.

[21]G. Lee, H. Lin, G.-G. Lee, and H.-F. Lin, "Distribution management customer perceptions of e-service quality in online shopping customer perceptions of e-service quality in online shopping,” Int. J. Retail Distrib. Manag., 2005.

[22]H. Sun and P. Zhang, "Causal relationships between perceived enjoyment and perceived ease of use: An alternative approach," J. Assoc. Inf. Syst., 2006.

[23] V. Venkatesh, M. G. Morris, G. B. Davis, and F. D. Davis, "User acceptance of information technology: Toward a unified view," MIS Q. Manag. Inf. Syst., 2003.

[24]F. D. Davis, R. P. Bagozzi, and P. R. Warshaw, "User acceptance of computer technology: A 
comparison of two theoretical models," Manage. Sci., 1989.

[25]M. R. Solomon, Consumer Behaviour: Buying, Having, and Being, 10th ed. Prentice-Hall, New Jersey, 2013.

[26]P. Kotler and G. Armstrong, Principles of Marketing. England, 2014.

[27] L. G. Schiffman, L. L. Kanuk, and H. Hansen, Consumer Behaviour, 2nd ed. 2012.

[28] S. A. Taylor and T. L. Baker, "An assessment of the relationship between service quality and customer satisfaction in the formation of consumers' purchase intentions,” J. Retail., 1994.

[29]H. Van Der Heijden, T. Verhagen, and M. Creemers, "Understanding online purchase intentions: Contributions from technology and trust perspectives,” Eur. J. Inf. Syst., 2003.
[30] Sugiyono, "Educational Research Methods Quantitative, Qualitative, and R\&D," 2013.

[31]M. Idrus, "Metode Penelitian Ilmu Sosial Pendekatan Kualitatif dan Kuantitatif," in Erlangga, 2009.

[32]D. Sutomo, "Pengaruh perceived ease of use, perceived usefulness, dan percived risk terhadap intention to transact pada toko online di Surabaya," J. Ekon., vol. 1, no. 1, 2012.

[33] Sulistiyono, “Analisis pengaruh kegunaan produk, kemudahan penggunaan produk, dan pergaulann social terhadap minat mereferensikan pada produk Blackberry di Kota Semarang," 2011 